\title{
Sprawozdanie z drugiej edycji projektu \\ „W poszukiwaniu świadka historii \\ - święta i uroczystości \\ podczas II wojny światowej"
}

Idea projektu „W poszukiwaniu świadka historii - święta i uroczystości podczas II wojny światowej”, zrodziła się kilka lat temu w trakcie współpracy Centrum Dokumentacji Deportacji Górnoślązaków do ZSRR w 1945 roku z młodzieżą szkolną. Zauważyliśmy, że wielu młodych ludzi interesuje się historią lokalną i szuka atrakcyjnych dla siebie form przekazu. W tym samym czasie nawiązaliśmy współpracę z Domem Współpracy Polsko-Niemieckiej, dotyczącą współtworzenia Archiwum Historii Mówionej. Zaangażowani w rejestrowanie opowieści świadków historii postanowiliśmy włączyć młodzież w utrwalanie lokalnego dziedzictwa. W $2016 \mathrm{r}$. zorganizowaliśmy konkurs pt.: „W poszukiwaniu świadka historii”. Nadesłanych zostało ponad 8o prac konkursowych. Duże zainteresowanie wydarzeniem utwierdziło nas w przekonaniu, że historia mówiona jest dla młodzieży atrakcyjną metodą odkrywania przeszłości, a techniczna strona sporządzania relacji pozwala na wykorzystywanie preferowanych przez nich technologii informatycznych. Wyposażeni w doświadczenia i wnioski 
z przeprowadzonego konkursu, przystąpiliśmy do przekształcenia formuły imprezy w wydarzenie cykliczne, składające się z trzech etapów: warsztatów, konkursu oraz tworzenia internetowego archiwum historii mówionej. Plan przeprowadzenia drugiej edycji projektu „W poszukiwaniu świadka historii" docenił dyrektor Muzeum Historii Polski, który przyznał dotację na realizację zadania w ramach programu „Patriotyzm Jutra”, a Śląski Kurator Oświaty objął wydarzenie honorowym patronatem.

W lipcu 2018 r. rozpoczęliśmy realizację zadania. Celem projektu była popularyzacja historii mówionej na Górnym Śląsku, jako metody urozmaicającej edukację historyczną. Dodatkowo za cel obraliśmy szerzenie świadomości w zakresie ochrony lokalnego dziedzictwa oraz zwrócenie uwagi na korzyści płynące z dialogu międzypokoleniowego. W podjętych działaniach wspierał nas partner - Dom Współpracy Polsko-Niemieckiej, który od 10 lat prowadzi warsztaty dla młodzieży oraz gromadzi relacje świadków historii w internetowym Archiwum Historii Mówionej na stornie: www.e-historie.pl.

Obchody stulecia istnienia państwa polskiego zainspirowały nas do tego, by drugą edycję projektu poświęcić świętom i uroczystościom obchodzonym przez mieszkańców Górnego Śląska. W drugiej edycji projektu wraz z młodzieżą poszukiwaliśmy rozmówców, którzy wspominali ważne rocznice i święta obchodzone w przeszłości oraz towarzyszące im zwyczaje, symbole, sposoby celebrowania itp. Chcieliśmy, by uczniowie dostrzegli, w jakim stopniu dawne sposoby świętowania zmieniły się w stosunku do praktyk znanych im ówcześnie, a także zwrócić ich uwagę na trwałość pewnych tradycji świątecznych, składających się na nasze dziedzictwo kulturowe.

Problematyka historyczna uwzględniona w scenariuszu merytorycznym zadania skoncentrowana była głównie na okresie II wojny światowej i pierwszych powojennych latach. Po wybuchu wojny rozpoczęła się okupacja niemiecka, przedwojenną polską część województwa śląskiego wcielono do III Rzeszy. Mieszkańców zmuszano do podpisania Volkslisty, powoływano do Wehrmachtu. W 1945 r. na tereny te wkroczyły wojska radzieckie. Dokonywano masowych mordów, gwałtów, grabieży. Wielu cywilów pozbawiono życia. W lutym Państwowy Komitet Obrony ZSRR wydał dyrektywę o zmobilizowaniu obywateli Rzeszy Niemieckiej w wieku od 17 do 50 lat do pracy przymusowej na terenie Związku Radzieckiego. Efektem dyrektywy były aresztowania i deportacja ok. 45 tys. Górnoślązaków do obozów pracy przymusowej m.in. w Doniecku, Mińsku, Bordżomi, Kemerowie.

Rytm życia na Górnym Śląsku w tym okresie został zaburzony. Pracując z młodzieżą, przyjęliśmy, że kontekst historyczny wpływał na sposoby 
obchodzenia świąt. W związku z tym zachęcaliśmy uczestników do dopytywania świadków historii m.in. o to, czy w okresie wojennym mieszkańcy Górnego Śląska skłonni byli do obchodzenia świąt i uroczystości. Czy głęboko wierzący Górnoślązacy będący np. uczestnikami walk zbrojnych, jeńcami wojenni, więźniami obozów lub deportowanymi do ZSRR pamiętali o świętach kościelnych lub innych dorocznych uroczystościach?

Sierpień 2019 r. poświęciliśmy na promocję projektu. Nasze przedsięwzięcie objęte zostało patronatem medialnym przez TVP Katowice. Plakaty promujące projekt oraz artykuły pojawiły się w lokalnej prasie, np. tygodniku „Gwarek” i w „Życiu Bytomskim”. Wzięliśmy także udział w kilku audycjach radiowych na antenie Meloradia, Radia eM, Radia Piekary oraz programach stacji telewizyjnych, np. Sfera TV.

Od września 2019 r. przystąpiliśmy do przyjmowania zgłoszeń. Projekt skierowany był do młodzieży z województwa śląskiego powyżej piątej klasy szkoły podstawowej oraz ich nauczycieli. Udział zgłosiło 85 uczniów reprezentujących 19 szkół. Młodzież pochodziła z różnych miejscowości, m.in. Bytomia, Tarnowskich Gór, Chorzowa, Zabrza, Gliwic, Radzionkowa, Sośnicowic, Syrynii.

W październiku odbył się pierwszy etap projektu. Zorganizowaliśmy dwa dni warsztatów, w trakcie których uczestnicy zdobyli odpowiednie umiejętności, potrzebne do rejestrowania opowieści świadków historii. Partner, wykorzystując swoje doświadczenie, przeprowadził warsztaty dotyczące historii mówionej. Podpowiedział m.in., o co pytać, by wywiad miał wartość historyczną. Ponadto zaprezentował i przeanalizował z młodzieżą przykłady dobrze i źle przeprowadzonych wywiadów. Dziennikarz dr Rudolf Urban podzielił się z uczestnikami swoim doświadczeniem w zakresie przeprowadzania wywiadów ze świadkami historii. Psycholog Marta Błońska poprowadziła warsztaty, które uwrażliwiły uczestników na różnice pokoleniowe oraz komunikacyjne, z jakimi mogą zetknąć się podczas rozmów z seniorami.

Po zakończeniu warsztatów rozpoczął się drugi etap projektu, w którym przewidzieliśmy czas na indywidualną pracę młodzieży. Młodzi badacze mieli okazję zweryfikować swoje umiejętności, spotykając się ze świadkiem historii. Ich zadaniem było wcielenie się w rolę historyków-badaczy i utrwalenie w formie nagrań audio lub audio/wideo wywiadów ze świadkami historii na temat jednego święta lub uroczystości, którą nagrywani przeżyli w okresie II wojny światowej. W ten sposób pośrednimi uczestnikami projektu zostali seniorzy. Konkurs zmobilizował młodzież do dialogu międzypokoleniowego, co najlepiej obrazuje szeroki przedział wiekowy wszystkich 
zaangażowanych - najmłodszy badacz miał niespełna 10 lat, a najstarszy świadek historii 96 lat. Dzięki relacjom seniorów uczniowie poszerzyli swoją wiedzę na temat realiów i warunków życia podczas II wojny światowej.

Sporządzone relacje wraz z opracowanymi kartami wywiadów uczestnicy zgłaszali do konkursu. Listopad upłynął pod znakiem przyjmowania prac oraz ich oceniania przez jury w składzie: dr Joanna Lusek - kierownik Działu Historii Muzeum Górnośląskiego w Bytomiu, od 2017 r. opiekun naukowy projektu „Archiwum Historii Mówionej” prowadzonego przez Dom Współpracy Polsko-Niemieckiej; dr hab. Maciej Fic - pracownik naukowo-dydaktyczny Instytutu Historii Uniwersytetu Śląskiego w Katowicach, badacz i popularyzator historii Górnego Śląska; oraz Judyta Ścigała - historyk, pedagog, specjalista ds. edukacji w Centrum Dokumentacji Deportacji Górnoślązaków do ZSRR w 1945 roku.

Jurorzy oceniali wartość historyczną, poprawność merytoryczną nagranych opowieści, a także techniczną stronę sporządzonych nagrań. Uczestnikom konkursu udało się zarejestrować wiele opowieści na temat Świąt Wielkanocnych, Bożego Narodzenia, komunii, wesel, pogrzebów, które organizowała ludność cywilna w czasie II wojny. Pojawiły się także narracje dotyczące świętowania urodzin Adolfa Hitlera czy świąt Bożego Narodzenia obchodzonych przez żołnierzy Wehrmachtu, a także deportowanych do ZSRR.

Uczestnicy oceniani byli w dwóch kategoriach wiekowych: szkoły podstawowe i gimnazja oraz szkoły ponadgimnazjalne. W każdej z kategorii wyłoniono po trzech laureatów, a także przyznano wyróżnienia. Ponadto dyrektor Centrum Dokumentacji Deportacji Górnoślązaków do ZSRR w 1945 roku podjął decyzję o przyznaniu 13 nagród specjalnych.

Po wyłonieniu laureatów organizatorzy przystąpili do tworzenia internetowego archiwum historii mówionej na stronie www.deportacje45.pl. Zbiór, który powstał z prac konkursowych, zawiera interesujące narracje dotyczące różnych aspektów życia m.in. mieszkańców Górnego Śląska. Choć za cezurę czasową gromadzonych opowieści przyjęliśmy okres II wojny światowej i pierwsze lata po niej, niektórzy świadkowie swymi wspomnieniami przenoszą słuchaczy także do innych okresów. Nagrania pogrupowane zostały w bloki tematyczne.

Wręczenie nagród odbyło się 7 grudnia 2018 r. w Centrum Dokumentacji Deportacji Górnoślązaków do ZSRR w 1945 roku. W uroczystości uczestniczyli laureaci oraz świadkowie historii. Spotkanie połączone było z promocją internetowego zbioru relacji opublikowanego na naszej stronie internetowej. 
Druga edycja projektu „W poszukiwaniu świadka historii” odbiła się szerokim echem poza województwem śląskim. Zostaliśmy zaproszeni do przedstawienia naszych działań podczas Ogólnopolskiej Giełdy Projektów w Białymstoku, organizowanej przez Narodowe Centrum Kultury. Dzięki temu nawiązaliśmy współpracę z innymi animatorami oraz wymieniliśmy się doświadczeniami.

Ideę przedstawionego projektu kontynuujemy w następnych przedsięwzięciach. Od lipca 2019 r. w Centrum Dokumentacji Deportacji Górnoślązaków do ZSRR w 1945 roku prowadzimy trzecią edycję projektu „W poszukiwaniu świadka historii”. Pierwszy etap realizowany był dzięki dotacji z programu „Bardzo Młoda Kultura - województwo śląskie” w ramach współpracy z Regionalnym Instytutem Kultury w Katowicach. Nowym partnerem trzeciej edycji projektu został Ośrodek „Pamięć i Przyszłość”.

Dzięki współpracy z młodzieżą stajemy przed niebywałą okazją do zatrzymania czasu - utrwalania odchodzących razem ze świadkami historii opowieści o niezwykłych wydarzeniach, przełomowych momentach, przeżytych tragediach czy praktykach dnia codziennego. Wszystko to, co kryje się pod płaszczem ludzkich wspomnień, dołączamy do naszej kolekcji, która liczy już prawie 200 relacji i stale się rozrasta. 